\title{
Extreme Cities and Bad Places
}

\author{
Paola Viganò* \\ Department of Urbanism, University IUAV of Venice (Istituto Universitario di Architettura di Venezia), 30125 Venice, Italy
}

\begin{abstract}
This article considers places where climate change-induced hazards will be particularly important, focusing on two examples, the lagoon location of Venice and the Garonne riverbank location of Bordeaux. The Venice lagoon territory is close to the coast and has a dispersed form of urban development. Our project experiments resulted in the formulation of a series of adaptation strategies to increased disaster risks, including returning current agricultural land and residential areas to their original state as wetlands and marshes before their reclamation during the early decades of the twentieth century. The scenarios introduce space as a relevant variable into the debate about the impact of climate change and adaptation. This article also deals with the recovery of "bad places," such as the urban blight on the Garonne riverbanks of Bordeaux, and their relationship with sustainability and disaster risks. Increasingly, the emphasis on minimizing energy consumption and promoting recycling forces cities to reuse places of elevated risk. Only very recently in modern urban planning are polluted and risky areas frequently selected for new development projects to reclaim the vast areas of existing brownfields in the name of sustainability. Integrating disaster risk reduction into a new economic and social context has thus become an extremely important part of contemporary urban design and planning for these reclaimed (bad) areas. The research concludes that urban and territorial design should and can integrate the inevitability of risk. This is necessary for developing approaches and strategies that offer some rethinking about "wicked" problems, long-term time horizons, radical imagination, dynamic representations, and minute territorial readings in contemporary urban planning.
\end{abstract}

Keywords Bordeaux, risk and sustainability, urban and territorial design, urban development scenario construction, Venice, water management

\section{Extreme City and Disaster Risk Reduction}

The Extreme City research project ${ }^{i}$ deals with places at the highest risk in Europe due to rising sea level that affects urbanized coasts as well as riverbanks and lagoons. The following section discusses the results of projects developing coping strategies for climate change-induced hazards in the Veneto region, focusing on flood risk prevention measures.

\footnotetext{
* E-mail: paola.vigano@secchi-vigano.it
}

\subsection{The Research Trajectory}

The "new modernity" corresponds to the social configuration defined by Beck as the "industrial society of risk." In Beck's framing of the issue, "the social production of wealth systematically goes hand in hand with social production of risks" (Beck 1986). Today, beyond Beck's proposition, in an era of grave economic and political crisis, risk seems to increase on its own, independent from the social production of wealth. In the "diffuse city" of the Italian Veneto region, the areas of urban dispersion we have studied, their businesses, and especially the small and medium industries, are facing fundamental crises that are reconfiguring the economic and territorial landscapes. ${ }^{\text {ii }}$ Due to neglect and lack of maintenance the system of dykes, ditches, and canals is often unable to cope with extreme weather conditions. The inability to invest in common goods and obliviousness of disasters reflect society's collective lack of consciousness about risk. Contemporary habits and ways of living continue to reduce permeable areas in a place that has always been vulnerable to disasters related to water.

Our research on climate change-induced hazards started from the water system and the interwoven road network that spread over the "diffuse city" (Indovina 1990; Secchi 1991) in the Venetian metropolitan area, one of the most dispersed territories in Italy and in Europe. It began with the Landscapes of Water research program in 2005 (Viganò et al. 2009); continued with Water and Asphalt-The Project of Isotropy ${ }^{\mathrm{iii}}$ in 2006 (Viganò 2008, 2011; Secchi 2011); and proceeded to the Extreme City project (Fabian and Viganò 2010). Reading the phenomena of settlement dispersion from the infrastructural point of view (Figure 1), our approach revealed not only the structuring capacity of the main water and transportation networks inside a city traditionally considered as chaotic and problematic in its spatial organization, but also the increasingly close and complex relationship between territory, settlements, and disaster risks. An extreme urban form, isotropic and low density, with a thick network of rivers and canals, and vast open and cultivated areas, this place suffers particularly from severe hydraulic risks that affect the daily lives of many of its inhabitants in increasingly profound ways.

The assumption of our research is that this diffused city form can reveal unexpected capacities to face environmental problems and meet sustainability requirements. But it needs 

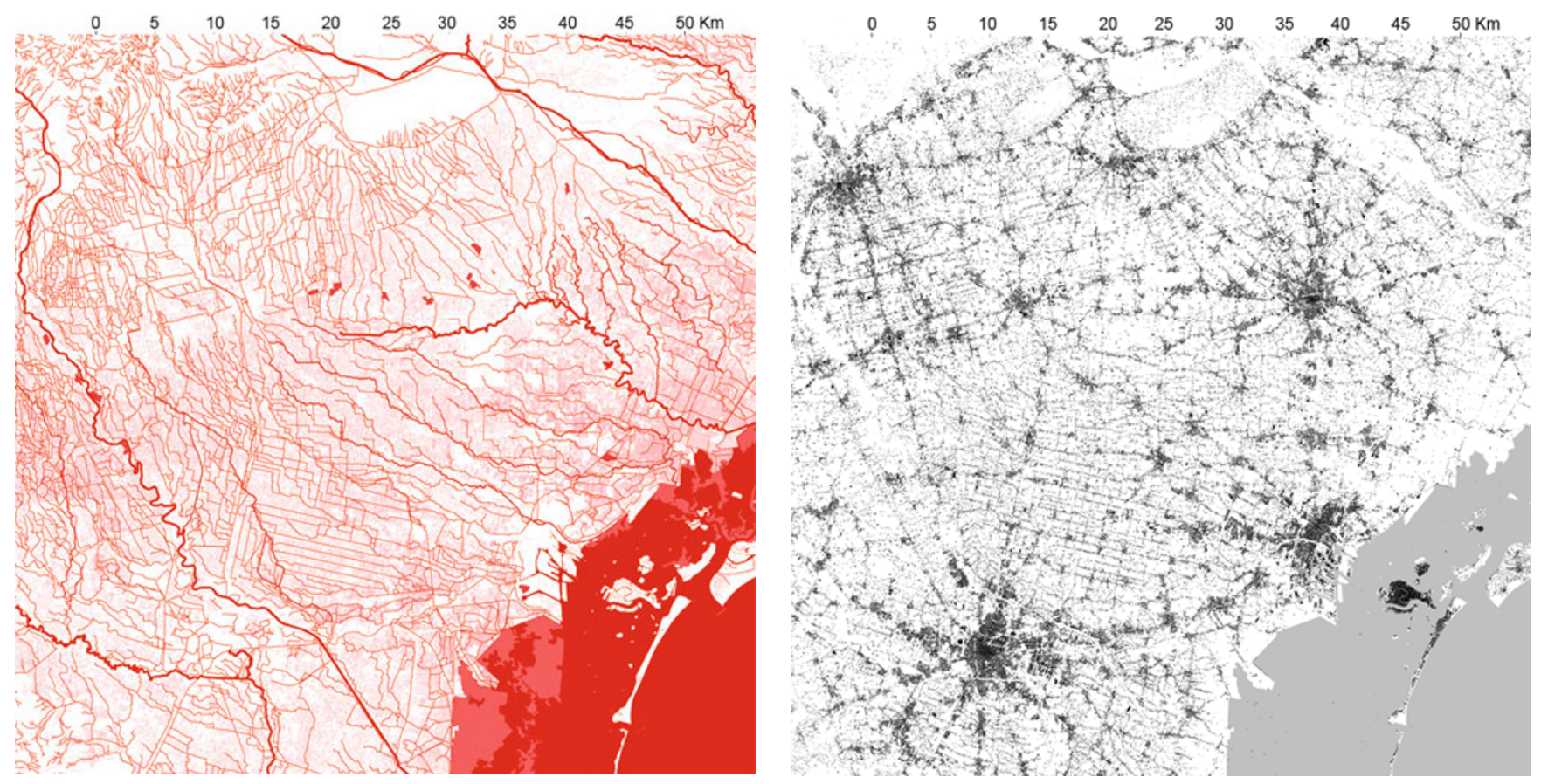

Figure 1. The water system (left) and built space (right) of the metropolitan area of Venice

Red: natural and artificial water systems; Gray: built settlements.

Source of data: Carta Tecnica Regione Veneto (2007).

Graphs elaborated by P. Viganò, L. Fabian, and C. Cavalieri. Reprinted with permission.

explicit and proper design and planning to compensate for and overcome many of its inadequacies.

Venice is an extreme case of controlling natural processes starting from sophisticated water management covering a vast territory, not only that of the lagoon (Cosgrove 1990; Bevilacqua 1998). For this reason, our studies initially analyzed the forms of water management in the Venice metropolitan area, which are highly complex in nature, and traced some threads of the area's long environmental history during which an amphibious ${ }^{\mathrm{iv}}$ or hydraulic culture was formed. This culture is characterized by meticulous maintenance of the water network for all the different purposes and is accustomed to risk, but has partially disappeared during the process of modernization.

Figure 2 shows the 5-m contour line identifying European lowlands vulnerable to significant sea level rise and risk of flooding. It reveals several "extreme territories" along the European coast, including ancient land reclamation areas and industrial areas in transformation. Climate change will render the territories of Venice even more vulnerable in the future, making it an "extreme city" from both a morphological and topological point of view and in terms of disaster risks.

The strategies we have proposed comprise some radical changes including returning parts of the agricultural land to the sea or to the lagoon. These scenarios also analyzed the impact on the settlements from implementing these strategies. The Venice lagoon area is regarded as a place that cannot totally give way to water due to historical, cultural, and ecological reasons. Flood prevention technologies have been employed, trying to resist rising water by heightening the level of the pavements inside the city or devising mobile

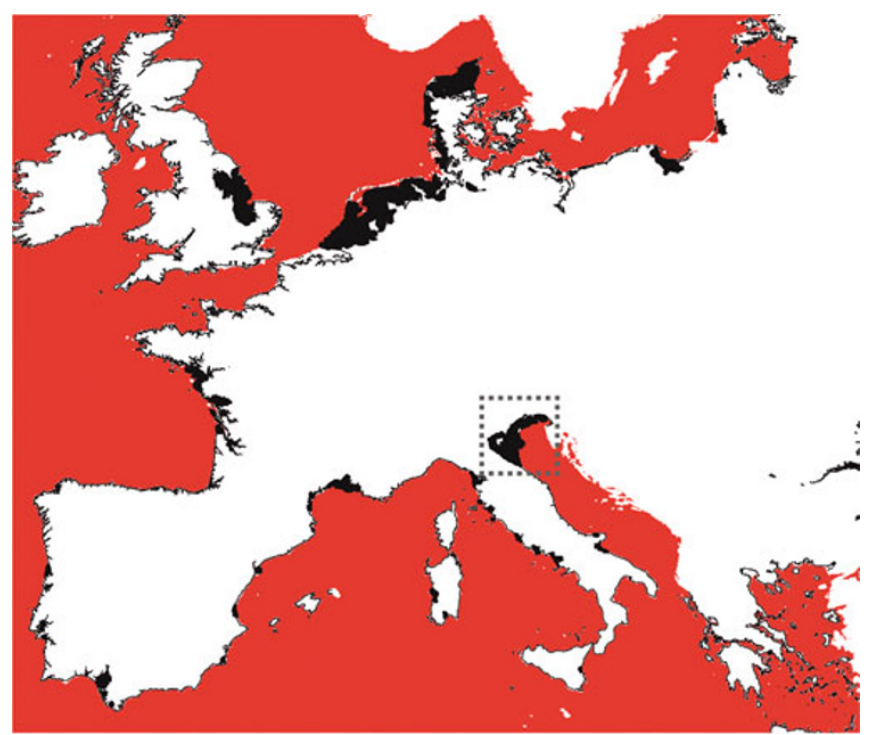

Figure 2. The 5-m contour line of lowlands vulnerable to sea level rise and flooding in parts of Europe

Black: flood risk with 5-m sea level rise; gray dash-line box: location of the Veneto region.

Source of data: EEA - EUROSION 2004.

Graph elaborated by P. Viganò, L. Fabian, and C. Cavalieri. Reprinted with permission. 
barriers against high water, such as the construction of the MOSE Project-a large barrier project now under completion. These flood defense projects improve the resistance of the territory, meaning the ability to be undisturbed by events, but the place remains very fragile and can easily be struck by extreme events. However, in the interior areas of the Venice metropolitan region, flood risk can be reduced through more resilient strategies, for example by improving the capacity to evacuate from the minor water system, imagining interventions that adapt areas temporarily to perturbations and allow them to regain their former status over time (Klein, Nicholls, and Thomalla 2003), such as allowing temporary flooding of certain places and returning them to their regular use after the events. This approach allows an ecosystem to endure and persist, albeit with many periods of instability and great heterogeneity (Holling 1973). Beyond the case of the city of Venice, it is interesting to reflect on a new balance between resistance and resilience at the regional scale and to adapt the existing infrastructure to the new urban conditions arising from climate change, associated risks, and contemporary values.

Hydraulic risk and the social production of wealth, resilience and instability, and social and natural risks are the three issues that structured our research in the Veneto area. This research takes a transect across a mountain-to-lowland landscape as an analytical and design tool for understanding the disaster risks of the territory and to formulate adaptation strategies to climate change. The territorial transect also allows us to bring the many spatial differences that distinguish one area from another to the fore.

\subsection{The Transect as an Analytical and Design Tool}

Our analysis is based on a transect that intersects the plain north of Venice from northwest to southeast, delimited by the mountains and the sea (see Figure 3). ${ }^{\mathrm{v}}$ Below the mountains, it crosses a dry plain in the north where the subsoil is composed of gravel. In the dry plain, the difficulty lies in providing water for irrigation, avoiding its immediate infiltration into the water table and purifying the infiltrated water in order to decrease the current pollution levels. The relation to water is the opposite in the central wet plain with clay soil where the problem is drainage. Along the central wet plain, the ancient roman centuriatio, a system of land subdividing, road and drainage network, reclaimed by monks in the middle ages, weaves its way at different angles to accommodate slopes and allow water to flow away from the impermeable ground. This system of generalized accessibility and water management has structured the diffuse city growth, but its efficacy has been compromised by the lack of maintenance as a result of reduced awareness of flood risk and change of primary economic activities. The increasing impermeability of the territory because of urban land use makes it even more compelling to restore the system's efficiency in order to face the increasing extreme rain events.
In the fifteenth century, the great diversion of rivers entering the lagoon was initiated by the Venetian Republic in order to avoid filling the water body with sand and gravel from the northern mountains. Rivers were displaced to the east and west of the lagoon in an incredible endeavor that gave origin to the new science of hydraulics thanks to Galileo. During the Fascist period of the 1930s, colossal reclamation works were carried out in the low-lying wetland areas around the lagoon through polderization similar to the Dutch flood defense approach. This transformation was intense enough to completely change the land's physical and ecological characteristics, using complex systems of dykes, ditches, and pumping stations to create new areas for intensive agriculture (Bevilacqua 1989; Bianchi 1989).

The transect illustrates the impossibility of formulating any design strategy without a clear understanding of the different characteristics of various parts of the territory and the unique water, environmental, and development problems they face. The difficulty of analyzing hydraulic risk is aggravated by interdependencies among the different parts of the territory that climate change renders even more important and visible. The main elements of the strategy of mitigation and adaptation we have proposed are connected to the area between the mountains and the lagoon. They consist of the idea of allowing the low-lying areas close to the lagoon to be flooded again by remodeling the low wet plain and changing its current use that has been developing since the large reclamation of the last century; using and reinforcing the existing embankments that protect the settlements and may support new interventions; enlarging the space of the rivers in the low impermeable plain; using the clay and gravel pits in the dry plain for storing water and purifying it so that it infiltrates into and replenishes the groundwater table; and reusing the canal network to reconstruct the drainage system in the wet plain. Between the wet and the dry plain, the spring line is a fragile area that must be protected from pollution. Here reforestation and ecological agriculture might help redesign the rural landscape and improve its ecological qualities. Although each of these strategies can be conceived and put into practice separately with no reference to one another, the power of the idea of the transect is to reconnect places and territories with a broader common vision of restoration and improvement.

In this context, we have attempted to use climate change as a "connector" (Sassen 2009), a global risk that can define new relations and approaches, and as such can be a conceptual, technical, social, and political catalyst. The advantage of choosing climate change impact over traditional views on water resources management and spatial planning clarifies the connections across the plain and the need of new alliances among disciplines such as urbanism, landscape ecology, hydraulic engineering, and rural urbanism.

\section{Bad Places and Lucky Coincidences}

Places with elevated environmental and natural disaster risks from industrial pollution in the past and high exposure to 


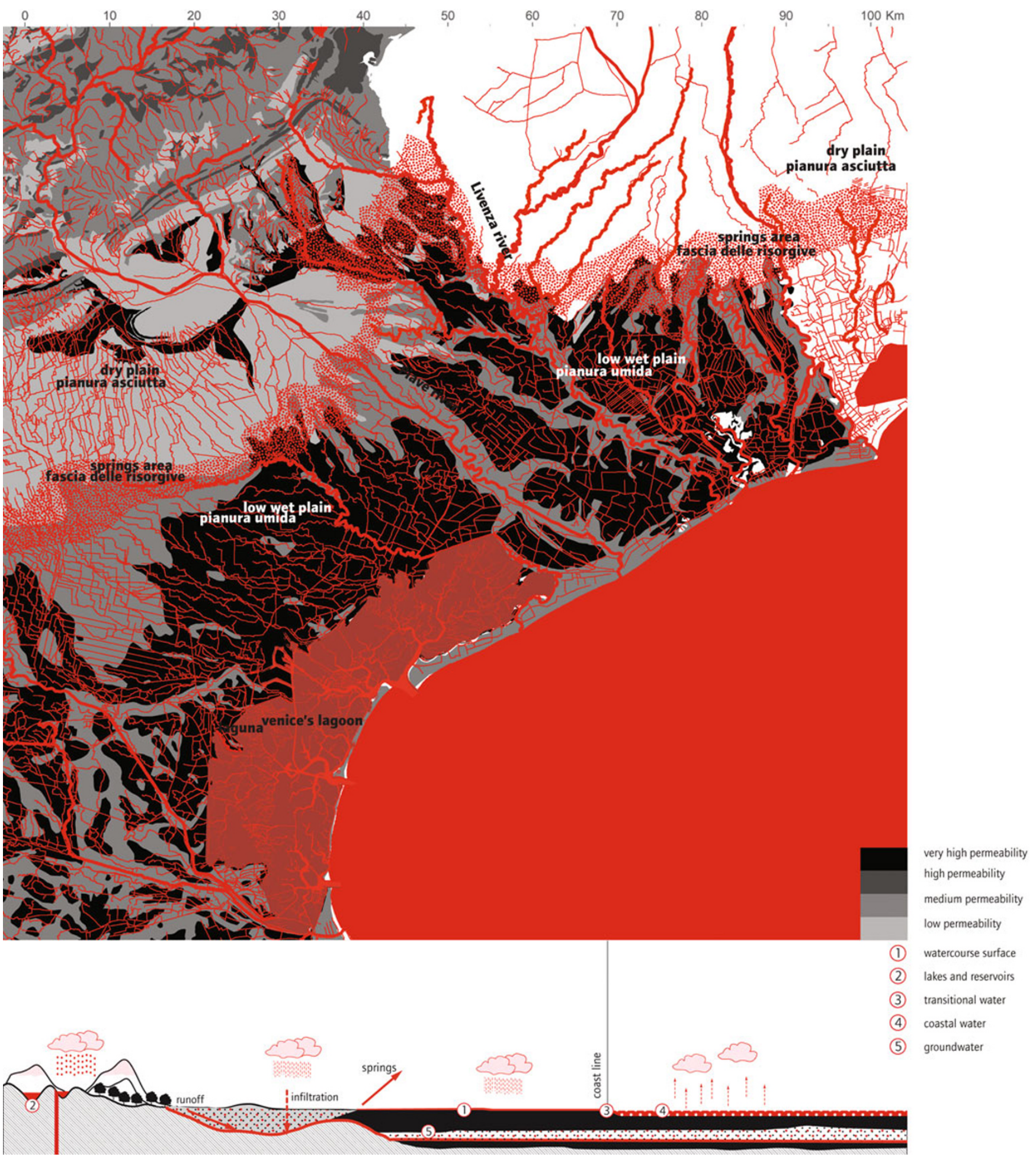

Figure 3. Map and section diagram of water system and land surface permeability of Veneto region

Source of data: Regional Territorial Coordination Plan (Department of Land Policies, Veneto Region 2009); Water Protection Plan (ARPAV 2006). Graphs elaborated by P. Viganò, L. Fabian, and C. Cavalieri. Reprinted with permission. 
natural hazards are increasingly used for urban development. In this section, results of a different type of research "by design," the outcome of an international competition about the reuse of a vast area on the right bank of the Garonne River in Bordeaux, France, are discussed. ${ }^{\mathrm{vi}}$

\subsection{The Garonne Eiffel Urban Recovery Project}

Through this urban recovery design exercise the relationships between "bad places" and sustainable development are explored. "Bad places" are areas that are today selected for new urban projects but were in the past used for heavy industrial purposes, often located in areas of high natural disaster risk, flooding in this case. Along with growing interest in the issue of sustainability since at least the Brundtland Report Our Common Future (UNWCED 1987), cities (intended as political and social bodies) are reclaiming areas of relatively high risk that can find a new life through projects for their recovery and reuse. For the first time in the history of modern urbanism, starting from the hygienist movement in the second part of the eighteenth century with its emphasis on better sanitarian urban conditions and healthier cities, urban growth does not proceed on well-selected green fields, or in the best areas for settlement, but in those where a number of environmental and/or disaster risks have accumulated, often in relation to their industrial past. Modern urbanism had been, in the past, selecting for all, the rich and the poor, the best (or "good") places. Today, in the name of sustainable development, urban designers confront themselves with recovering and recycling more difficult and "bad" areas, thus avoiding the consumption of more green fields.

With this new cultural and pragmatic approach, the integration of risky areas into new forms of habitat also means an opportunity for innovative projects proposing strategies to address this condition, starting from a careful examination of the territory and its characteristics. It is not only a general move in favor of sustainability, but also a technical and concrete attempt to reflect on resilient design.

In recent years, the urban recovery of Bordeaux in the west of France ${ }^{\text {vii }}$ has stimulated national and international discussion about the city's new appeal. Between 1999 and 2008, Bordeaux added about 20,000 new residents and many new jobs - a success that gained much media visibility in urban and architecture magazines. An intelligent policy for the recovery of public space, especially along the left bank of the Garonne River, rendered spaces previously occupied by port activities or traffic inhabitable once again and intensively used by local residents, city users, and tourists. The arrival of the TGV (high-speed train), expected in 2017, will support and reinforce a growth similar to that of recent years. Within the perspective of creating proactive attractiveness guided by strong political goals (to reach the dimension of a metropolis with one million inhabitants), the areas along the Garonne, upon which the city had turned its back until the late 1990s, are again strategic and have become candidates for major transformation.
We have approached the Garonne Eiffel area, the site of the urban design competition for a new neighborhood for about 7000 new inhabitants, as a palimpsest (Corboz 1983) a repository of stories, and industrial and infrastructural interventions of the past centuries - upon which a new urban layer will be added. It is a question of imagining new life cycles for a territory that has already had many: from swamp to a place of pleasure with villas and cultivated countryside, to an industrial site and dense infrastructure, and then a place of abandonment.

The interest of the exercise lies in understanding the potential and strengths of every object on site: concrete plate, railway fragment, wrecks of ancient structures, built-on marshland still revealed by depressions on the terrain, its clay texture and low permeability. During the industrialization process that started at the beginning of the nineteenth century, along with the building of railway lines and the Pont de Pierre connecting the two banks of the Garonne, modest and weakly structured urbanization took over part of the area. In the 1960s, industrial activities near the banks, the river port, and rail lines began their decline and in some cases were replaced, most recently, by logistics activities. ${ }^{\text {viii }}$

Today the Garonne Eiffel site, on the right bank of the Garonne, is targeted by a plan for 7000 new housing units and approximately $200,000 \mathrm{~m}^{2}$ of offices and facilities (Figure 4), such was the program of the competition, and it is a place where flood risk is present and high. The industrial past is visible in abandoned buildings, but also in the significant pollution of waters and soils. These conditions create an undeniable opportunity (a reserve of land near the city center) together with significant challenges for building an urban area that can consciously face the risk of flooding and reduce the risk from soil pollution, all with inexpensive techniques and methods. These were the goals that our design project was to face.

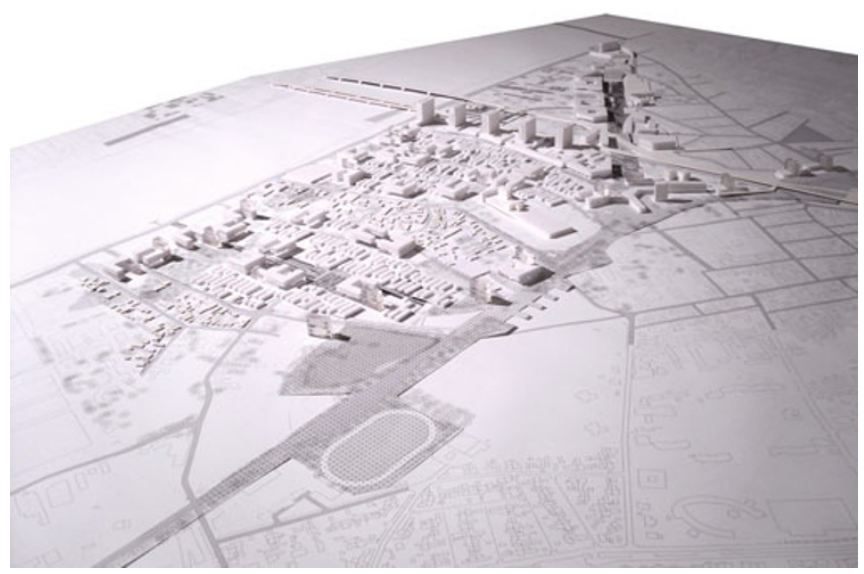

Figure 4. Model of the Garonne Eiffel urban recovery project on the right bank of the Garonne River, with residential and office/commercial buildings, a park, and elements from its industrial past

Source: Studio Associato Bernardo Secchi Paola Viganò. Reprinted with permission. 


\subsection{Lucky Coincidences and Risk Management}

The goal is to modify existing situations, taking advantage of what already exists and revealing through design "lucky coincidences," that is casual relations between urban and natural materials due to urban stratification that enhance the positive aspects of the spatial structure of the site. Our proposal $^{\mathrm{ix}}$ is to design a series of bands perpendicular to the river, often guided by the secondary rivers, tributaries of the Garonne (underground or channeled in the past), or abandoned rail lines, marked by dense vegetation. These elements of the landscape at the Garonne site may result in an open public space, a park that can be created with little effort, transforming a set of barriers into a new device to connect different parts of the city. New thinking - inevitably experimentalhad to be developed for hydraulic risk management within this new setting. In addition to complying with current regulations and trying to anticipate future changes in design codes that take into consideration climate change impact in an area frequently subject to flooding, the project proposes the following actions: (1) prohibiting building in areas where water can reach a height of over one meter above the existing ground level; (2) prohibiting building within a distance from the existing protection wall 100 times its height $(1 \mathrm{~m} \mathrm{high})$; (3) using building types that might work with floodable ground floors, and taking into account the possibility of the protection wall failure by raising the first floor level to a given height, together with paths that guarantee accessibility in case of flooding; and (4) maintaining non-built areas at higher altitudes (still flood-prone but to a lesser extent) and near the bridge in order to accommodate the population that might be hit by flood events. In the last case, the building-free areas provide space and connections for a part of the population who has no other way of finding refuge and access to the existing bridge in case of flooding. The large void on the side of the bridge and of the boulevard that connects the city center of Bordeaux to the right bank of the river plays the role of a "space-monument" placed in front of the large monumental UNESCO-protected facade on the left bank.

Our project design was largely based on these principles, throughout the process ranging from flood risk assessment to thinking about the urban scale. This is not an issue of building a few, isolated objects, but requires thinking about the possibility of building an entire area of the city that is subject to flooding, in which critical mobility should be guaranteed along with the main connections and local centers of activities. These principles were proposed to guide an extensive transformation that needs to be gradual in time and space, and the construction of an inhabitable but amphibian place in which the project modularity has evolutional characteristics. This briefly described exercise leads to several considerations.

Before we can create a resilient city in its entirety, we need to start by designing a resilient project in order to advance our state of knowledge and understanding about important issues. A resilient city is a place that does not loose accessibility and basic inhabitability during flooding events. Evacuation of population does not conform to this requirement. A resilient city is also a place that survives through time and events (Holling 1973): considerable public space leaves the possibility open for future adjustments. Modularity of the different urban fabrics that allow the composition of articulated, flexible, and "measured" inhabited spaces is an important characteristic of a resilient urban space.

The resilient city is an open structure that can adapt and weave new links, using, as we tested in our project design, a dual scale of the space-monument and the domestic one. The first creates a relationship between the new urban park and the large eighteenth-century monumental facade on the other side of the river, and the second constructs a minute and domestic amphibian fabric, taking advantage of lower floodable areas (free from buildings and where existing ones should shrink in the future) as points of high vegetation density and new area of high biodiversity. All of this implies progressive knowledge of the site and its most polluted places, minimizing ground movements and monitoring its constantly evolving economic and social conditions.

As Lynch stated in What Time is This Place (Lynch 1972), the cities that have best withstood time are those that have these characteristics. The more recent emergence of the paradigm of resilience recalls these ideas and approaches.

\section{Risk and Design}

The two examples of Venice and Bordeaux presented above have raised many questions about urban and regional design and planning with regard to the management of environmental and natural disaster risks.

\subsection{Thinking in the Long Term: Towards the Future, towards the Past}

First, the examples show that long-term climate change and impact have entered our daily lives. It has become even more important today to place urban and territorial design thinking into a long-term framework. This applies to climate change adaptation, but it is also increasingly necessary for understanding the areas at risk in which we operate. The reconstruction of the environmental history of areas and the deep understanding of the process of social and ecological transformation of every place are essential for contemplating adequate plans and projects. Only the comprehension of the relationships established over time between urban, social, economic, and environmental dynamics helps us to distinguish what may persist despite disturbances (and is resilient). It is clear that knowledge of the long term requires intersecting points of views and disciplines.

The long time frame of environmental history enters into any exercise of territorial design. It can provide understanding of actual ecological dynamics and help to conceive future adaptations through the construction of scenarios. In the first 
research on the Venice metropolitan region, it has been fundamental to maintain dual perspectives: towards the past and towards the future. This forward movement can only develop if supported by broader considerations, and therefore a stronger relationship of the urban project with the human and social sciences is needed.

\subsection{Wicked Problems and Risk Society}

In these, as in other cases of urban design and planning, the formulation of goals, the definition of the problems, and the issue of spatial justice (Soja 2010) seek to meet in a field that is never, or very rarely, clearly defined. For example, there is still no global consensus on the need for strong engagement against climate change and to reach such consensus locally is even more difficult. It is the field of the wicked problems which Rittel and Webber (1973) already raised. The conflict between actions that decrease risk by giving more space to water and actions to increase resistance (with dams, dykes, and so on) in order to maintain a strong agricultural sector is a clear example of the different interests behind technical choices in the Veneto region.

Problems tied to risk are often intractable, or close to it; they are difficult to define and even more difficult to resolve because they are destined to remain open and constantly require new solutions, or simply new reconstructions. So in the social condition represented in Risk Society by Beck (1986), the contribution of design lies in its ability to reconstruct the problem - the issue of environmental risk, its social, economic, and political roots; to construct possible scenarios, and to explore their consequences.

The project that can face the wicked problems of the contemporary territory is a highly imaginative and radical project. In the case of the Venice metropolitan area, energy and mobility scenarios developed in the Water and Asphalt research (Viganò 2008, 2011; Secchi 2011) show how the existing territorial isotropic structure can support a "no car" region in which an improved public transport system can be the starting point for a project to regenerate the entire diffuse city and decrease $\mathrm{CO}_{2}$ emissions. The point is not to respond with an endless proliferation of alternatives, but to use design to investigate and produce knowledge (Viganò 2010a) in order to achieve objectives, advance technologies, and understand the values expressed by society.

\subsection{Representing Time}

Dealing with the environmental history of a place involves an exchange of information among different disciplines and the collection of data and its representation over a long time frame. In some cases, the very mapping of places reveals changes over time, as shown by the images of the most important rationalizations, that is, territorial modifications that involved the Venice metropolitan area from the vast Roman land divisions draining and structuring the land more than two thousand years ago. Each time, shifting between the long and short terms reveals different behaviors of adaptation, deformation, or resistance of places.

The representation of dynamic, provisional, and deformed conditions is an exercise that is not used often enough during the design process; but it is fundamental for conceiving the project, to gain access, for example, to three-dimensional simulations in which, as in Bordeaux, different conditions of inhabitability are defined with different spatial devices.

Taking into account the long time frame also opens up different images of the future that can be represented in models, views, and short stories showing that unexpected juxtapositions and new coexistences can be contemplated.

\section{Conclusion: Alternative Futures}

The Extreme City research emphasizes the need to radicalize our design activity as a way to consciously avoid the "naturalization of social relations of inequality and power" connected to climate change, its growing risks, and catastrophes whose natural evidence is sometimes evoked (Beck 2010). This means repositioning design as an activity that reengages itself in the social arena. Design is not socially and politically neutral, but a tool aware of the differences that depend on and are introduced by spatial choices (Lefebvre 1974). To be radical without losing the enormous potential of each place, exploring the consequences of all possible changes in space or lifestyles, yet remaining very close to concrete situations, is the core of the Water and Asphalt and Extreme City research approach and of the test project of Garonne Eiffel in Bordeaux.

Reversing the idea of abstract radical thinking, the nuanced interpretation of site-related characteristics and conditions can reveal ways of functioning, asking for choices, and evolving into models that might be shared with other contexts. This is the purpose of the transect designed for the Venice metropolitan area. Broader than the area itself, running from the mountains to the plains, it describes a landscape and territorial management system that integrates the different strategies on adaptation to climate change related to water and landscape features. All these proposals, standard procedures if we take them one by one or piece by piece, if coupled with a drastic shift to the use of public transport and reduction of energy consumption, might have a radical impact, not only on the landscape and levels of risk, but also on economies, lifestyles, everyday habits, and rules for territorial construction.

\section{Notes}

i The project was funded by a European Intensive Program (Lifelong Learning Program of the European Commission Framework 7 Program) in 2010.

ii In the Veneto region several paradoxes have arisen. As in other territories of dispersion, significant causes of crises are changing the typical traits of the diffused city as it has been described since 
the end of the 1970s. "The development without fractures" has been theorized in Italy by economists, sociologists, geographers, and urbanists (Fuà and Zacchia 1983), especially during the last twenty years (Indovina 1990; Secchi 1991). This type of spatial development is characterized by a mix of housing and working in an extended territory, with people usually living in single detached houses and working in small enterprises.

iii The research, coordinated by Secchi and Viganò and conducted by Ph.D. students at IUAV, was presented at the 10th International Architecture Biennale of Venice in 2006.

iv Petra van Dam, Professor of Water History at the Free University of Amsterdam, uses this definition to describe the specific ability to live with water and to manage it in the Netherlands over the last six centuries.

v Here I develop some considerations made in Viganò $2010 \mathrm{~b}$.

vi The competition concerned the Accord-Cadre de Maitrise d'ouvre Urbaine Secteur «Garonne Eiffel» (Framework Agreement for Urban Sector Project Management), October 2011 organized by the CUB - Communauté Urbaine de Bordeaux.

vii See, for example, the intensive activities of urban regeneration since the mayor of the city, Alain Juppé, promoted the construction of the new tramway lines. See also the intensive planning and urban design activities described in the books published by the Direction Générale de l'Aménagement de la ville de Bordeaux (Urban Planning Management Department): 2030 Vers le Grand Bordeaux, une métropole durable $(2030$ Greater Bordeaux, a Sustainable Metropolis), 2009; or Habiter Bordeaux, la ville-action (To Live in Bordeaux, a City of Action), 2011.

viii The materials accompanying the competition contained detailed analyses of the existing structures.

ix Studio Associato Bernardo Secchi Paola Viganò (with A. Calò, D. Chang, U. degli Uberti, E. Giannotti, I. Mancini, C. Pisano, L. Rudko, R. Sega, and Q. Zhang) has been selected among the five invited teams to make a proposal for the site Garonne Eiffel urban recovery project in Bordeaux. The multidisciplinary group was also supported by Arcadis and P. Baylac (Hydro-expert), consultants for ecological programs and energy issues (Villes et Paysages, Tribu, ORGECO, 2EI) and COCO.

\section{References}

ARPAV (Veneto Environmental Protection Agency). 2006. Water Protection Plan (Piano di Tutela delle Acque). Veneto Environmental Protection Agency.

Beck, U. 1986 (English translation 1992). Risk Society: Towards a New Modernity (Risikogesellschaft - Auf dem Weg in eine andere Moderne). Frankfurt a/M: Suhrkamp.

- 2010. Social Inequality and Climate Change. In Ecological Urbanism, edited by M. Mostafavi. Cambridge, MA and Baden, Switzerland: Harvard University Graduate School of Design, Lars Müller Publishers.

Bevilacqua, P. 1989. The Revolutions of Water. Irrigation and Transformation of Agriculture between the 18th and the 20th Century (Le rivoluzioni dell'acqua. Irrigazioni e trasformazioni dell'agricoltura tra Sette e Novecento). In History of Italian Agriculture in Contemporary Times (Storia dell'agricoltura italiana in età contemporanea), Vol. I, edited by P. Bevilacqua, 255-318. Venice: Marsilio.

1998. Venice and the Sea. A Planetary Metaphor (Venezia e le acque. Una metafora planetaria). Rome: Donzelli.

Bianchi, B. 1989. The New Plain, the Landscape of Reclaimed Land in the Po Valley (La nuova pianura, Il paesaggio delle terre bonificate in area padana). In History of Italian Agriculture in Contemporary
Times (Storia dell'agricoltura italiana in età contemporanea), Vol. I, edited by P. Bevilacqua. Venezia: Marsilio.

Corboz, A. 1983. The Land as Palimpsest. Diogenes 31 (121): 12-34.

Cosgrove, D. 1990. Platonism and Practicality: Hydrology, Engineering and Landscape in Sixteenth-Century Venice. In Water, Engineering and Landscape, edited by D. Cosgrove and G. Petts. New Delhi: CBS Publishers.

Department of Land Policies, Veneto Region. 2009. Regional Territorial Coordination Plan (PTCR, Piano Territoriale di Coordinamento Regionale). Veneto Region.

EEA (European Environment Agency) - EUROSION. 2004. Five Meter Elevation Contour Line. http://www.eea.europa.eu/data-and-maps/ data/five-meter-elevation-contour-line.

Fabian, L., and P. Viganò, eds. 2010. Extreme City. Climate Change and the Transformation of the Waterscape. Venice: IUAV Press.

Fuà, G., and C. Zacchia, eds. 1983. Industrialization without Fractures (Industrializzazione senza fratture). Bologna: Il Mulino.

Holling, C. S. 1973. Resilience and Stability of Ecological Systems. Annual Review of Ecology and Systematics No. 4: 1-23.

Indovina, F., ed. 1990. The Diffuse City (La città diffusa). Venice: Department of Social and Economic Analysis of Land (Dipartimento di Analisi Economica e Sociale del Territorio), IUAV (Istituto Universitario di Architettura di Venezia).

Klein, R. J. T., R. J. Nicholls, and F. Thomalla. 2003. Resilience to Natural Hazards: How Useful is This Concept? Environmental Hazards 5 (1-2): 35-45.

Lefebvre, H. 1974. The Production of Space (La production de l'espace). Paris: Anthropos.

Lynch, K. 1972. What Time is This Place? Cambridge, MA: MIT Press.

Rittel, H. W. J., and M. M. Webber. 1973. Dilemmas in a General Theory of Planning. Policy Sciences No. 4: 155-69.

Sassen, S. 2009. Bridging the Ecologies of Cities and Nature. In The New Urban Question, Urbanism beyond Neo-Liberalism, edited by J. Rosemann and D. Sepulveda. Rotterdam: Ifou.

Secchi, B. 1991. The Periphery (La periferia). Casabella No. 583.

. 2011. Isotropy vs. Hierarchy. In Landscapes of Urbanism, Q5, edited by V. Ferrario, A. Sampieri, and P. Viganò. Rome: Officina.

Soja, E. W. 2010. Seeking Spatial Justice. Minneapolis: University of Minnesota Press.

UNWCED (United Nations World Commission on Environment and Development). 1987. Our Common Future (Brundtland Report). Oxford: Oxford University Press.

Urban Planning Management Department of Bordeaux (Direction Générale de l'Aménagement de la ville de Bordeaux). 2009. 2030 Greater Bordeaux, a Sustainable Metropolis (2030 Vers le Grand Bordeaux, une métropole durable). Bordeaux: Ville de Bordeaux.

. 2011. To Live in Bordeaux, a City of Action (Habiter Bordeaux, la ville-action). Bordeaux: Ville de Bordeaux.

Viganò, P. 2008. Water and Asphalt: The Project of Isotropy in the Metropolitan Region of Venice. Architectural Design 78 (1): 34-39.

2010a. The Territories of Urbanism. Design as Knowledge Producer (I territori dell'urbanistica - Il progetto come produttore di conoscenza). Rome: Officina (French translation: 2012. Les territoires de l'urbanisme. Geneva: MetisPresses).

2010b. Extreme City: A Design and a Research Theme. Introduction. In Extreme City - Climate Change and the Transformation of the Waterscape, edited by L. Fabian and P. Viganò. Venice: IUAV Press.

2011. The Project of Isotropy. In Landscapes of Urbanism, Q5, edited by V. Ferrario, A. Sampieri, and P. Viganò. Rome: Officina.

Viganò, P., U. degli Uberti, T. Lombardo, G. Lambrecht, and G. Zaccariotto. 2009. Landscapes of Water (Paesaggi dell'acqua). Pordenone: Risma.

Open Access This article is distributed under the terms of the Creative Commons Attribution License which permits any use, distribution, and reproduction in any medium, provided the original author(s) and source are credited. 